\title{
A Species-Specific PCR Based Assay for Rapid Detection of Mango Anthracnose Pathogen Colletotrichum gloeosporioides Penz. and Sacc.
}

\author{
M Kamle ${ }^{1 *}$, B K Pandey ${ }^{1}$, P Kumar $^{1}$ and Muthu Kumar M ${ }^{2}$ \\ ${ }^{1}$ Division of Crop Protection, Plant Molecular Pathology Lab, Central Institute for Subtropical Horticulture, Rehmankhera, Lucknow, India \\ ${ }^{2}$ Division of Crop Improvement and Biotechnology, Central Institute for Subtropical Horticulture, Rehmankhera, Lucknow, India
}

\begin{abstract}
Mango (Mangifera indica L.) a fruit of nutraceutical value is accepted as the most eatable fruit crop worldwide. Mango production has been severely affected by several biotic stress mainly diseases and anthracnose is the major post-harvest disease of mango results in heavy losses. The present investigation describes PCR based assay for rapid and sensitive detection of Colletotrichum gloeosporioides causing mango anthracnose. Genus specific universal primer pair ITS1 and ITS4 was employed to amplify Colletotrichum genus which shows $\wedge 560 \mathrm{bp}$ amplicon. The Colletotrichum gloeosporioides species-specific sequences for conserved domains were retrieved from the NCBI Genbank (sequence HM10205) and specific primers were designed. In order to validate the speciesspecific designed primer, a sensitive nested PCR assay was carried out using designed primer-pair MKCgF 5 TTGCTTCGGCGGGTAGGGTC 3’ (forward) and MKCgR 3`ACGCAAAGGAGGCTCCGGGA 5’ (reverse) produced an amplicon size of $380 \mathrm{bp}$ as specific. Our investigation revealed that $C$. gloeosporioides causal agent of mango anthracnose was discriminated on the basis of species as specific for mango in comparison to other Colletotrichum spp. viz. C. acutatum, C. falcatum and C. capsici causing anthracnose in other crops.
\end{abstract}

Keywords: PCR; Internal transcribed spacer region; Species-specific; Diagnosis

\section{Introduction}

Mango (Mangifera indica L.) is considered as one of the most popular fruits grown throughout the tropics and subtropics worldwide [1]. India is the world's largest producers, shares around $56 \%$ of total global production [2]. Production of mango is affected by a large number of fungal pathogens. The genus Colletotrichum contains many morphologically similar taxa comprising endophytic, saprobic and plant pathogenic fungi [3]. Of which, C. gloeosporioides an incitant of mango anthracnose is the most important biological constraint which restricts mango production in Southeast Asia [4]. C. gloeosporioides affects mango production both in the pre and post harvest stages particularly when attempting to extend storage life resulting in huge economic losses about $5-20 \%$ in the form of damage on the stems, leaves, fruit decay and damage [1,5]. Anthracnose disease is clearly identified by morphological symptoms but sometimes the symptoms are masked as this disease survived in the form of latent infection in absence of congenial environment. Symptom based identification and characterization is not accurate and reliable due to incipient infection. The diagnostic techniques, thus will assist in the monitoring the spread and distribution of pathogens. PCR technology can provide very accurate quantitative data required for control and quarantine decisions. The ability to design PCR primers to target specific regions of DNA has led to rapid, accurate, and sensitive detection which is a greater understanding for managing Colletotrichum diseases.

The development of species-specific primers has provided a powerful tool for the detection of plant pathogens. The identification of fungal pathogens based on polymerase chain reaction (PCR) using species-specific primers is now widely used, especially for economically important plant pathogens such as quarantine listed fungi or those that are difficult to isolate or cause symptomless [6,7]. The internal transcribed spacer regions (ITS1 and ITS4) within the nuclear ribosomal gene clusters are particularly attractive loci for the design of PCR-based detection assays since they are readily accessible using universal primers [8] typically present in high copy number increasing PCR sensitivity and often exhibiting sufficient inter-specific sequence divergence for the designing of species-specific primers [9]. In recent years, molecular tools have been employed to infer the evolutionary relationships of Colletotrichum species. Based on nu-rDNA ITS sequence data and morphological characteristics, some species have been segregated from the Colletotrichum gloeosporioides complex. Although ITS sequence data may help in Colletotrichum species identification, it cannot alone be used to adequately address species delimitation for closely related species [10]. Researchers have recently tried to examine multiple genes sequence data to distinguish species in Colletotrichum [10,11-16].

These regions can be further exploited for diagnostic purpose and the primers can be designed against species specific regions from rDNA. Therefore, a more contemporary approach aimed to develop a molecular diagnostic assay for rapid and accurate diagnosis against mango anthracnose pathogen for species-specific identification.

\section{Materials and Methods}

Thirty isolates of Colletotrichum gloeosporioides were collected from different agro-climatic mango growing regions of the India and reference pure culture were maintained and collected from leaf tissue and fruits affected with anthracnose. For further PCR assay

*Corresponding author: Madhu Kamle, Division of Crop Protection, Plant Molecular Pathology Lab, Central Institute for Subtropical Horticulture, Rehmankhera, Lucknow, India- 227107; E-mail: kamle_madhu@yahoo.co.in

Received May 22, 2013; Accepted June 03, 2013; Published June 10, 2013

Citation: Kamle M, Pandey BK, Kumar P, Muthu Kumar M (2013) A SpeciesSpecific PCR Based Assay for Rapid Detection of Mango Anthracnose Pathogen Colletotrichum gloeosporioides Penz. and Sacc. J Plant Pathol Microb 4: 184 doi:10.4172/2157-7471.1000184

Copyright: ( 2013 Kamle M, et al. This is an open-access article distributed unde the terms of the Creative Commons Attribution License, which permits unrestricted use, distribution, and reproduction in any medium, provided the original author and source are credited. 
standardization the 11 most pathogenic isolates of C. gloeosporioides collected from mango were procured. The details of colletotrichum gloeosporioides isolates collected and place of origin is given in Table 1.

\section{Fungal DNA isolation}

DNA extraction: The fungal mycelium and conidia from pure cultures, grown on one potato dextrose agar (PDA) (Himedia) petridish for 2 weeks at $25^{\circ} \mathrm{C}$ in the dark, were scraped and mechanically disrupted by grinding to a fine powder using a mortar and pestle. Total DNA was extracted with the Fast DNA Extraction Kit (MP Bio) following the manufacturer's instructions. Genomic DNA isolated was visualized under UV light on $0.8 \%(\mathrm{wt} / \mathrm{v})$ agarose gel stained with ethidium bromide and stored at $-20^{\circ} \mathrm{C}$.

\section{Species-specific primers designing}

Species-specific primers were designed using advanced bioinformatics tools and the sequence retrieved from the NCBI database (http//:www.ncbi.nlm.niv.gov.in) from accession no. HM102505 of Colletotrichum gloeosporioides [17] and the conserved sequences were then picked up through Genmark software and the multiple sequences were aligned through Clustal W. The primer designed through the software Primer 3 and confirmed through the repeated NCBI-Primer BLAST and synthesized by Metabion International Pvt. Inc. A sequence based species-specific primer were designed according to Kamel et al. [18] (Figure 1) for the identification of Colletotrichum gloeosporioides and validated with other species of Colletotrichum (Table 2).

\section{ITS-PCR}

The ITS rDNA region including ITS1, 5.8S and ITS4 were amplified in 11 isolates of C. gloeosporioides selected from different mango growing regions of India (Figure 2). The isolates were PCR amplified using the universal primers ITS1/ITS4 [8]. Each PCR reaction contained $1 \times$ PCR buffer, $2.5 \mathrm{mM} \mathrm{MgCl}_{2}, 200 \mu \mathrm{M}$ of each dNTP, $0.2 \mu \mathrm{M}$ of each primer, $0.7 \mathrm{U}$ of Taq DNA polymerase (Biochem), and $1 \mu \mathrm{l}$ of template DNA. The PCR reaction mix was adjusted to a final volume of $25 \mu \mathrm{l}$ with nuclease free water. PCR amplifications were performed on a Thermal Cycler (Eppendorf, India Limited). The program consisted of an initial step of $1 \mathrm{~min}$ at $94^{\circ} \mathrm{C}$ for $1 \mathrm{~min}$, followed by 30 cycles of $60 \mathrm{~s}$ at $94^{\circ} \mathrm{C}, 2 \mathrm{~min}$ at $58^{\circ} \mathrm{C}$, and $60 \mathrm{~s}$ at $72^{\circ} \mathrm{C}$; and a final extension step of 5 min at $72^{\circ} \mathrm{C}$. PCR products were analyzed in $1.5 \%$ agarose gel, stained with ethidium bromide and visualized under UV light. 100-bp DNA ladder plus was used as a molecular weight marker (Biochem).

\section{Results and Discussion}

Nuclear rDNA, including the small and large subunits, $5.8 \mathrm{~S}$, and the Internal Transcribed Spacer (ITS) region, proved an ideal target for specific PCR primers, as each sequence is variable at the family, genus, or species level [8]. Internal transcribed spacer (ITS) regions have been used successfully to generate specific primers capable of differentiating closely related fungal species [19]. Amplification of target DNA through PCR with taxon-specific primers is a potentially more sensitive and accurate approach than conventional microscopic techniques [2022]. Unlike identification based on culture techniques, PCR does not

\begin{tabular}{|c|c|c|c|c|c|c|}
\hline S. No. & Culture No. & Region of isolate & Symptom & $\begin{array}{l}\text { Pathogen } \\
\text { isolated }\end{array}$ & Sporulation & Metabolite colour \\
\hline 1 & $\mathrm{Cg} 1$ & Nallangandu-chittoor & $100 \%$ & C. gloeosporioides & +++ & White black \\
\hline 2 & Cg2 & chittoor & $100 \%$ & C. gloeosporioides & +++ & Yellow white black \\
\hline 3 & $\mathrm{Cg} 3$ & Totapur & $100 \%$ & C. gloeosporioides & +++ & Yellowish white \\
\hline 4 & $\mathrm{Cg} 4$ & Totapur & $40 \%$ & C. gloeosporioides & +++ & Yellowish white \\
\hline 5 & Cg5 & Bagampalli chittoor & $30-50 \%$ & C. gloeosporioides & +++ & Yellowish pink white \\
\hline 6 & Cg6 & Assam & $50 \%$ & C. gloeosporioides & +++ & Pink yellow white \\
\hline 7 & $\mathrm{Cg} 7$ & Guahati & $100 \%$ & C. gloeosporioides & +++ & (Rounded) black white \\
\hline 8 & Cg8 & Guahati & $70 \%$ & C. gloeosporioides & +++ & Black brown white \\
\hline 9 & Cg9 & Jorhat & $50 \%$ & C. gloeosporioides & +++ & White brown dots \\
\hline 10 & $\mathrm{Cg} 10$ & Jorhat & $100 \%$ & C. gloeosporioides & +++ & Brown orange dots \\
\hline 11 & Cg11 & Rewa (M.P.) & $100 \%$ & C. gloeosporioides & +++ & black white \\
\hline 12 & Cg12 & Rewa (M.P.) & $50 \%$ & C. gloeosporioides & +++ & White browm dots \\
\hline 13 & Cg13 & Akbarpur (U.P.) & $100 \%$ & C. gloeosporioides & +++ & White orange \\
\hline 14 & $\mathrm{Cg} 14$ & Akbarpur (U.P.) & $50 \%$ & C. gloeosporioides & +++ & White orange \\
\hline 15 & Cg15 & CISH Lucknow, (U.P.) (mallika) & $50 \%$ & C. gloeosporioides & ++ & White rounded \\
\hline 16 & Cg16 & Siliguri & $100 \%$ & C. gloeosporioides & +++ & White round \\
\hline 17 & Cg17 & Siliguri & $55 \%$ & C. gloeosporioides & ++ & Pink yellow white \\
\hline 18 & Cg18 & Tanda, (U.P.) & $80 \%$ & C. gloeosporioides & ++ & (Rounded) brown white \\
\hline 19 & Cg19 & Tanda (U.P.) & $100 \%$ & C. gloeosporioides & +++ & (Rounded) Yellowish white \\
\hline 20 & $\mathrm{Cg} 20$ & Dasehri leaf Lucknow & $100 \%$ & C. gloeosporioides & + & (Rounded) pink yellow white \\
\hline 21 & Cg21 & Lucknow & $100 \%$ & C. gloeosporioides & Nill & (Rounded) yellow white \\
\hline 22 & Cg22 & Lucknow & $100 \%$ & C. gloeosporioides & +++ & (Rounded) pink white \\
\hline 23 & Cg23 & Lucknow & $50 \%$ & C. gloeosporioides & + & Pink white \\
\hline 24 & Cg24 & Faizabad & $75 \%$ & C. gloeosporioides & +++ & (Rounded) yellow white \\
\hline 25 & Cg25 & Darjeeling & $100 \%$ & C. gloeosporioides & +++ & Yellowish white \\
\hline 26 & Cg26 & Gorakhpur & $10-30 \%$ & C. gloeosporioides & +++ & Yellowish white \\
\hline 27 & Cg27 & (Other leaf) & $100 \%$ & C. gloeosporioides & + & White \\
\hline 28 & Cg28 & Badlapur, (U.P.) & $100 \%$ & C. gloeosporioides & ++ & White \\
\hline 29 & Cg29 & Mujaffarnagar & $100 \%$ & C. gloeosporioides & +++ & (Rounded) white black \\
\hline 30 & $\mathrm{Cg} 30$ & Bihar & $100 \%$ & C. gloeosporioides & +++ & White \\
\hline
\end{tabular}

Table 1: Details of Colletotrichum gloeosporioides isolates collected from different agro-climatic regions of India causing mango anthracnose disease. 


\begin{tabular}{cccccc}
\cline { 4 - 5 } \cline { 4 - 5 } & ITS & $5.8 \mathrm{~S}$ & ITS & $28 \mathrm{SrR}$ \\
\hline rRNA & rRNA & 2 & NA \\
& & $560 \mathrm{bp}$ & & \\
ITS1 & & & &
\end{tabular}
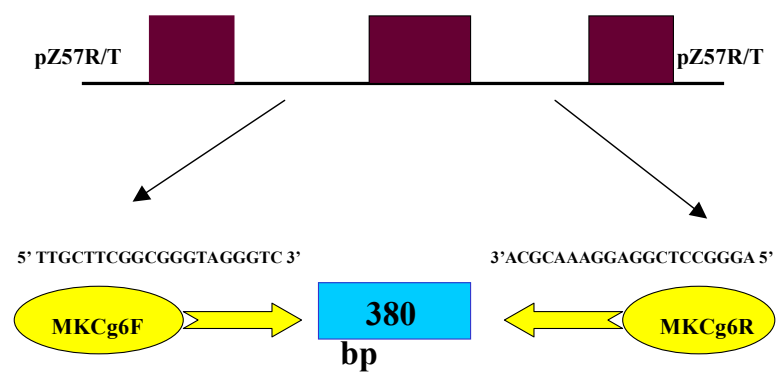

Figure 1: Internal Transcribed spacer (ITS) region primers ITS1 and ITS 4 [8] used for Colletotrichum species-specific primer designing.

\begin{tabular}{|c|c|c|c|}
\hline Primer & Sequence & $\begin{array}{l}\text { Product Size } \\
\text { (bp) }\end{array}$ & Origin \\
\hline ITS1 & TCCGTAGGTGAACCTGCGG & \multirow{2}{*}{560} & \multirow[t]{2}{*}{ White et al. [8] } \\
\hline ITS 4 & TCCTCCGCTTATTGATATGC & & \\
\hline MKCgF & TTGCTTCGGCGGGTAGGGTC & \multirow{2}{*}{380} & \multirow{2}{*}{$\begin{array}{l}\text { Species-specific } \\
\text { primer }\end{array}$} \\
\hline MKCgR & ACGCAAAGGAGGCTCCGGGA & & \\
\hline
\end{tabular}

Table 2: Details of primer sequences used for ITS-PCR.

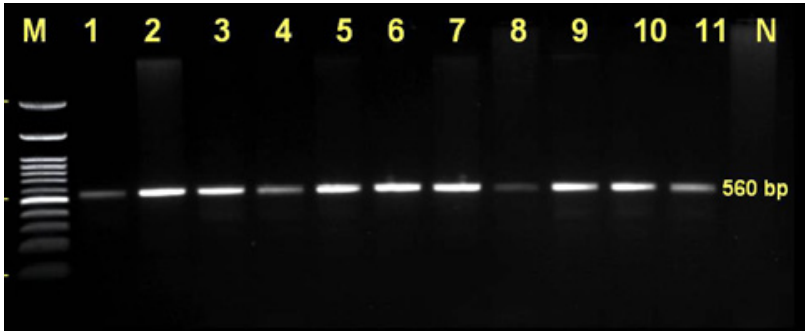

Figure 2: PCR amplification of Colletotrichum gloeosporioides using Fungus specific universal ITS1 and ITS4 primers which amplifies 560 bp uniform amplicon among all the 11 isolates collected from different geographical regions and LaneM-100 bp DNA Ladder (Biochem), Lane $\mathrm{N}$ is negative.

require the presence of viable organisms and can work even when there is a limited amount of sample [23]. In the present investigation, a sensitive PCR-based diagnostic assay were developed with the aim to detect Colletotrichum gloeosporioides mango anthracnose pathogen in infected plant and fruit tissue using species-specific designed primerpair. The specificity of this sensitive PCR-based assay was also verified by the absence of reactivity with DNA from uninfected (healthy) tissues and other Colletotrichum species. The $10 \mathrm{pg}$ to $10 \mathrm{mg}$ of genomic DNA of Colletotrichum spp. was found to be sufficient for a detectable PCR amplification. This is for the first time a PCR based diagnostic assay for early detection of mango anthracnose pathogen C. gloeosporioides was carried out using species-specific designed primer which amplifies a uniform band of $380 \mathrm{bp}$ among all the isolates (Figure 3) and clearly discriminated other species having no amplification with the designed primer as specific.

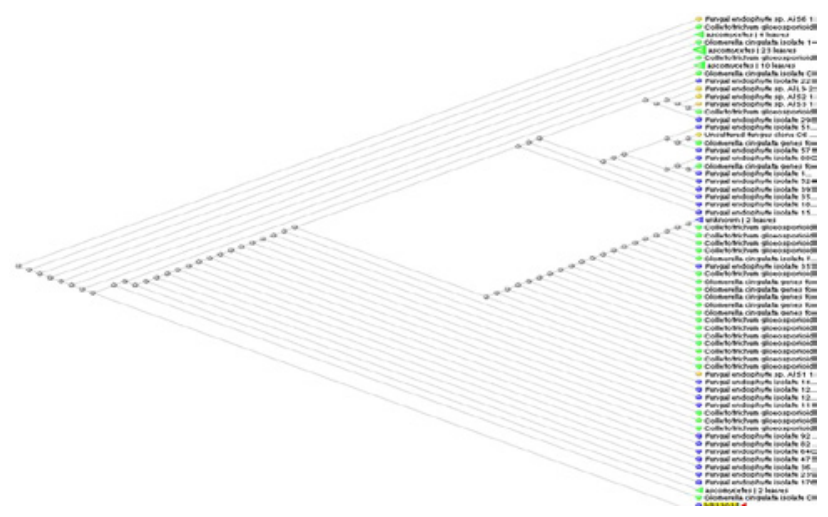

Figure 3: Taxonomy report of 11 Colletotrichum isolates showing maximum similarity about $99-100 \%$ with C. gloeosporioides with already available sequences at the NCBI web.

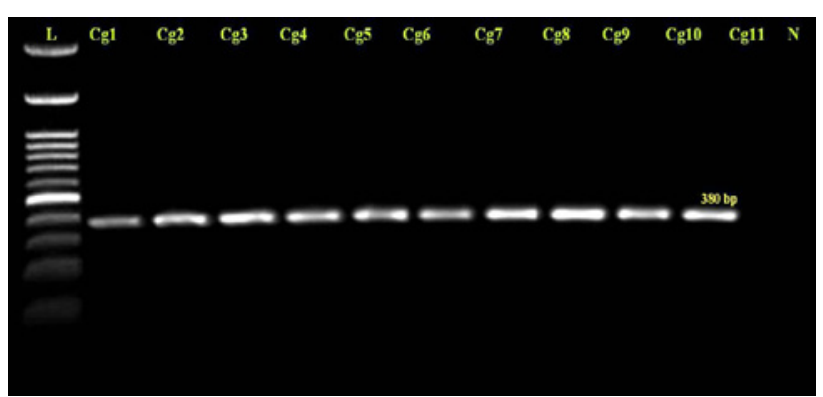

Figure 4: PCR amplification of C. gloeosporioides isolates using speciesspecific designed primer amplifies a uniform band of $380 \mathrm{bp}$ as desired among all the 11 isolates (Lane1-11) (Lane-N) negative control and Lane L-100 bp DNA Ladder (Biochem).

\section{Sequencing and data analysis}

The sequence information obtained for the twenty C. gloeosporioides isolates were analyzed by local alignment tool using BLASTn. Taxonomic correlation of the isolates upon NCBI web proved that the isolates were more related to C. gloeosporioides. All annotations were based on BLAST searches with a score threshold of e" 200 for BLASTn and e-values $10^{-5}$ with a minimum of $99-100 \%$ identity over at least $80 \%$ of the length of the nucleotide sequence which are the commonly used thresholds for reliable sequence annotation. Sequences were confirmed for identification using repeated blast with already available sequences for the identification and taxonomy of the C. gloeosporioides using the NCBI-BLAST search for sequence identification of BLAST 2.0 (http:// www.ncbi.nlm.nih.gov/BLAST) Figure 3.

\section{PCR amplification of species-specific designed primer}

DNA fragment of approximately $380 \mathrm{bp}$ were amplified for $C$. gloeosporioides using primer-pair MKCgF and MKCgR (Figure 4). No cross-amplification in other Colletotrichum sp., viz., C. falcatum, C. capsici (Figure 5). Thus, the diagnostic PCR approach yielded highly consistent and reproducible results. The first amplification with fungus specific primers preferentially increased the population of fungal ITS molecules, thereby increasing the ratio of fungus by host ITS molecules. Then, the PCR amplification with species-specific designed primer amplifies a PCR product of $380 \mathrm{bp}$ as specific for Colletotrichum gloeosporioides. Similarly, the existence of species-specific primers 


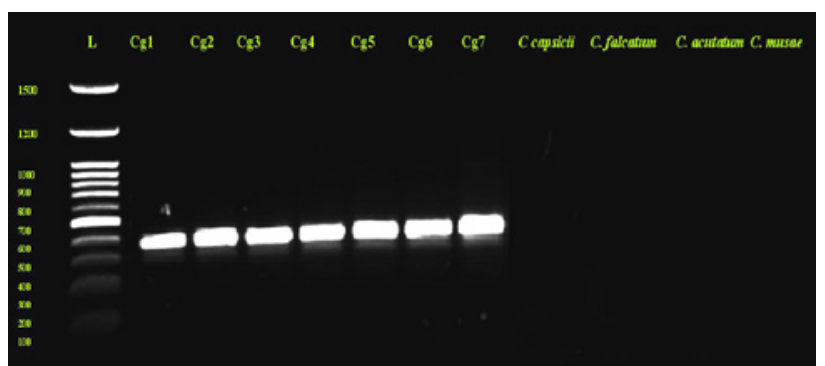

Figure 5: PCR amplification of C. gloeosporioides species-specific primer amplified a uniform band of $380 \mathrm{bp}$ as desired among all the 6 isolates (Lane2-7) Lane-L-100 bp DNA Ladder (Biochem) and no amplification in other host Colletotrichum species viz., C. falcatum, C. acutatum, C. musae and C. capsici.

based on nucleotides sequences of the ITS1 rDNA region have made the Polymerase Chain Reaction (PCR) a powerful tool for the identification of Colletotrichum species [23-27].

\section{Validation of species-specific primer with other Colletotrichum species}

PCR amplification of species-specific designed primer MKCgF and MKCgR gives amplicon size of $380 \mathrm{bp}$ uniformly amplifies in all the isolates of Colletotrichum gloeosporioides but, no amplification in other with other Colletotrichum species viz. C. accutatum, C. falcatum and C. capsici. In context to our findings, the designed primer-pair does not amplified in other Colletotrichum species which; clearly discriminates Colletotrichum gloeosporioides the pathogen of mango anthracnose (Figure 5) on the basis of species-specificity.

Identification of the causal agent and prevalence of a disease is very essential for adequate and timely management of disease, which in turns depends on accurate diagnosis and early detection of the pathogen. Often, it may be desirable to examine the planting material for prevalence of any potential pathogen even before the crop is sown. So, in the present investigation the species-specific designed primer-pair MKCgF and $\mathrm{MKCgR}$ for Colletotrichum gloeosporioides specifically for mango was designed and the primer has been validated with other Colletotrichum species. Thus, the designed primer proved to be an efficient marker for species-specific discrimination which would be useful in developing a rapid and sensitive diagnostic PCR based assay for early detection and timely management of Colletotrichum gloeosporioides causing mango anthracnose disease.

\section{Acknowledgement}

Authors are highly thankful to Director, Central Institute for Subtropical Horticulture, Rehmankhera, Lucknow for preparation of manuscript and providing necessary research facilities. Senior Research Fellowship to author (M. Kamle) of ICAR under Outreach Leaf Spot, Programme is gratefully acknowledged.

\section{References}

1. Dodd JC, Prusky D, Jeffries P (1997) Fruit diseases. In: The Mango: Botany, Production and Uses. CAB International, UK

2. Arauz LF (2000) Mango anthracnose: economic impact and current options for integrated management. Plant Dis 84: 600-611.

3. Photita W, Taylor PWJ, Ford R, Hyde KD, Lumyong S (2005) Morphological and molecular characterization of Colletotrichum species from herbaceous plants in Thailand. Fungal Div 18: 117-133.

4. Ploetz R (1999) Anthracnose: The most important disease in much of the mango producing world. The News Letter of the Plant Pathol 3: 1-6.

5. Akthar KP, Khan I, Khar IA, Khan SM (1998) Studies on the incident and pathogenesis of Colletotrichum gloeosporioides Penz. causing anthracnose of mango and chemical control. Pakistan J Phytopath 10: 42-44.

6. Hyun JW, Peres NA, Yi SY, Timmer LW, Kim KS, et al. (2007) Development of PCR assays for the identifications of species and pathotypes of Elsinoe causing scab on citrus. Plant Dis 91: 865-870.

7. Peres NA, Harakava R, Carroll GC, Adaskaveg JE, Timmer LW (2007) Comparison of molecular procedures for detection and identification of Guignardia citricarpa and G. mangiferae. Plant Dis 91: 525-531.

8. White TJ, Bruns T, Lee S, Taylor JW (1990) Amplification and direct sequencing of fungal ribosomal RNA genes for phylogenetics. In: PCR Protocols: A Guide to Methods and Applications, Academic Press, Inc., New York, USA.

9. Nieto Feliner G, Rosselló JA (2007) Better the devil you know? Guidelines fo insightful utilization of nrDNA ITS in species-level evolutionary studies in plants. Mol Phylogenet Evol 44: 911-919.

10. Crouch JA, Beirn LA, Cortese LM, Bonos SA, Clarke BB (2009) Anthracnose disease of switchgrass caused by the novel fungal species Colletotrichum navitas. Mycol Res 113: 1411-1421.

11. Du M, Schardl CL, Nuckles EM, Vaillancourt LJ (2005) Using mating-type gene sequences for improved phylogenetic resolution of Collectotrichum species complexes. Mycologia 97: 641-658.

12. Johnson DE, Carris LM, Rogers JD (1997) Morphological and molecula characterization of Colletotrichum nymphaeae and C. nupharicola sp. nov. on water-lilies (Nymphaea and Nuphar). Mycolog Res 101: 641-649.

13. Crouch JA, Tredway LP, Clarke BB, Hillman BI (2009) Phylogenetic and population genetic divergence correspond with habitat for the pathogen Colletotrichum cereale and allied taxa across diverse grass communities. Mo Ecol 18: 123-135.

14. Than PP, Jeewon R, Hyde KD, Pongsupasamit S, Mongkolporn O, Taylo PWJ (2008a) Characterization and pathogenicity of Colletotrichum species associated with anthracnose on chilli (Capsicum spp) in Thailand. Plant Pathology 57: 562-572.

15. Than PP, Shivas RG, Jeewon R, Pongsupasamit S, Marney TS, Taylor PWJ, Hyde KD (2008b) Epitypification and phylogeny of Colletotrichum acutatum J.H. Simmonds. Fungal Div 28: 97-108.

16. Moriwaki J, Tsukiboshi T (2009) Colletotrichum echinochloae, a new species on Japanese barnyard millet (Echinochloa utilis). Mycoscience 50: 273-280.

17. Kamle M, Kumar P, Gupta VK, Tiwari AK, Misra AK, Pandey BK (2013) Identification and phylogenetic correlation among colletotrichum gloeosporioides pathogen of anthracnose for mango. Biocatalysis and Agricultural Biotechnology.

18. Kamel AA (2003) Bioinformatic tools and guideline for PCR primer design. Afr J Biotechnol 2: 91-95.

19. Bryan GT, Daniels MJ, Osbourn AE (1995) Comparison of fungi within the Gaeumannomyces-Phialophora complex by analysis of ribosomal DNA sequences. Appl Environ Microbiol 61: 681-689.

20. Kamel A Abd-Elsalam, Ibrahim NA, Mohammed A Abdel-Satar, Mohmed S Khalil, Joseph A Verreet (2003) PCR identification of Fusarium genus based on nuclear ribosomal-DNA sequence data. African J Biotech 2: 82-85.

21. Farid B, Maria JF, Aziz M (2006) A rapid PCR based method to distinguish between Enterococcus species by using degenerate and species-specific sodA gene primers. Afr J Biotechnol 5: 697-702.

22. Kawther S (2008) Genotyping of bovine viral diarrhea virus using multiplex PCR with and without RNA extraction. Afr J Microbiol Res 2: 316-318.

23. Schubert R, Bahnweg G, Nechwatal J, Jung T, Cooke DEL, et al. (1999) Detection and quantification of Phytophthora species which are associated with root-rot diseases in European deciduous forests by species-specific polymerase chain reaction. Eur J For Pathology 29: 169-188.

24. Freeman S, Katan T, Shabi E (1996) Characterization of Colletotrichum gloeosporioides isolates from avocado and almond fruits with molecular and pathogenicity tests. Appl Environ Microbiol 62: 1014-1020.

25. Freeman S, Katan T, Shabi E (1998) Characterization of Colletotrichum species responsible for anthracnose diseases of various fruits. Plant Dis 82: 596-605. 
Citation: Kamle M, Pandey BK, Kumar P, Muthu Kumar M (2013) A Species-Specific PCR Based Assay for Rapid Detection of Mango Anthracnose Pathogen Colletotrichum gloeosporioides Penz. and Sacc. J Plant Pathol Microb 4: 184 doi:10.4172/2157-7471.1000184

Page 5 of 5

26. Freeman S, Minz D, Jurkevitch E, Maymon M, Shabi E (2000) Molecular analyses of colletotrichum species from almond and other fruits. Phytopathology 90: $608-614$
27. Peres NAR, Kuramae EE, Dias MSC, de Souza NL (2002) Identification and Characterization of Colletotrichum spp. Affecting fruit after Harvest in Brazil. Phytopathol 150: 128-134. 